\title{
1 Pathways of human development threaten biomes' protection and their 2 remaining natural vegetation
}

3

4 Isabel M.D. Rosa ${ }^{1}$, Carlos A. Guerra ${ }^{2,3}$

$5{ }^{1}$ School of Natural Sciences, Bangor University, Bangor, Gwynedd, LL57 2DG, United

6 Kingdom

$7 \quad{ }^{2}$ Institute of Biology, Martin Luther University Halle-Wittenberg, Am Kirchtor 1, 06108,

8 Halle (Saale), Germany

$9{ }^{3}$ German Centre for Integrative Biodiversity Research (iDiv) Halle-Jena-Leipzig, Deutscher

10 Platz 5E, 04103 Leipzig, Germany

12 Corresponding author: Isabel M.D. Rosa

13 School of Natural Sciences

14 Bangor University, Bangor, Gwynedd

15 LL57 2DG United Kingdom

16 E-mail i.rosa@bangor.ac.uk

17 Phone $+44(0) 1248383642$

18 ORCID: 0000-0001-8257-1963

20 Keywords: protected areas, land use change, scenarios, conservation targets, shared socio-

21 economic pathways

23 Running title: Threatening the remaining natural vegetation 


\section{Abstract}

28 Protected areas have been one of the most commonly applied conservation tools to prevent 29 ecosystem degradation. International conservation targets have been created to incentivize

30 widespread expansion of protected area networks, but this call might clash with expected

31 future land use change. Here we investigated how future land use trajectories (2015-2090),

32 representing a wide range of plausible future scenarios would impact the remaining areas of

33 primary vegetation under different protection levels across the world's biomes. We then

34 highlight areas under greater risk of conflict between conservation (highly protected) and

35 land use expansion (high projected change), and areas where these two can better co-exist

36 (lower protection with high projected change and/or high protection with low projected

37 change).

38 While the most positive pathway of development led to the least loss of primary vegetation

39 globally, this was not observed in all biomes. Further, we found no significant correlation

40 between existing extent of protection and average proportion of vegetation loss.

41 Mediterranean Forests, Woodlands \& Scrub had the largest projected loss occurring in the

42 highest protected areas. Tropical Forests in Central Africa and the Boreal Forests of North

43 Euro-Asia and Canada emerge as the areas where most projected change occurs, and existing

44 protection is still low. Areas in India and Southeast Asia emerge as potential areas for

45 intervention as they have significant projected loss of primary vegetation, and considerably

46 low protection.

47 Our results can help inform policy and decision-makers to prevent such conflicts and support

48 the development of management actions. These policy and management actions should target

49 conservation in areas under expected great pressure of change with high ecological value

50 (e.g., composed mainly by primary vegetation), but still not protected. This study also opens

51 the discussion to the future of current protected areas and to the potential to expand the

52 existing network of protected areas. 


\section{$54 \quad$ Introduction}

55 Humans have been degrading and shaping landscapes worldwide for many centuries

56 (Ellis \& Ramankutty, 2008). In fact, in 1700, nearly half of the terrestrial biosphere was wild,

57 whereas by 2000, the majority of the terrestrial ecosystems was already converted into

58 agricultural lands and settlements, leaving less than $20 \%$ of semi-natural areas and only a

59 quarter left wild (Ellis, Klein Goldewijk, Siebert, Lightman, \& Ramankutty, 2010). This trend

60 of human modification of landscapes is expected to continue as human population keeps

61 increasing and, as a consequence, so does the demand for agricultural and forest products

62 (Boserup, 2017). Moreover, as humans convert natural habitats (Gibbs et al., 2010), the

63 world's biomes and ecoregions become more degraded, jeopardizing these as habitats for

64 species and hampering the benefits people derive from them (Díaz et al., 2018; Hoekstra,

65 Boucher, Ricketts, \& Roberts, 2005). A central challenge of achieving sustainability is,

66 therefore, how to preserve natural ecosystems while enhancing food production (Lambin \&

67 Meyfroidt, 2011).

Protected areas have long been used as important conservation tools to prevent ecosystem degradation and preserve biodiversity and ecosystem services vital to sustain human livelihoods (Watson, Dudley, Segan, \& Hockings, 2014). As such, the number of protected areas has increased greatly since the 1990s (Anthamatten \& Hazen, 2015). However, the overall coverage of these areas is still rather low, i.e. roughly $12-13 \%$ (Anthamatten \& Hazen, 2015; Brooks, Da Fonseca, \& Rodrigues, 2004; Jenkins \& Joppa, 2009), reducing to $9.3 \%$ when considering well-connected protected areas (Saura, Bastin, Battistella, Mandrici, \& Dubois, 2017). There is, nonetheless, international pressure to increase this coverage, especially by the establishment of international conservation targets, such as the Aichi Targets, specifically Target 11, which states that by 2020 at least $17 \%$ of terrestrial areas are conserved through well-connected systems of protected areas (https://www.cbd.int/sp/targets/). This call to expand protected areas might clash with the expected expansion of agricultural lands for food production and other types of land use change.

The relationship between the effectiveness and the placement of these protected areas has been a great source of debate. Claims have been made that protected areas are often located in remote areas (Joppa \& Pfaff, 2009), isolated and with low population densities 
86 (higher slope, further from roads and cities) to explain why they suffer less degradation

87 (Schulze et al., 2018). Others, however, have shown the 'pulling' effect of these areas, with

88 land cover change occurring closer to protected areas than in more distant unprotected lands

89 (Guerra et al. in review). Simultaneously, it has been shown that pressure on protected areas

90 has increased over time (Geldmann, Joppa, \& Burgess, 2014), particularly in developing

91 countries threatened by resource (over)exploitation (Schulze et al., 2018). Nonetheless, there

92 is mounting evidence that protected areas have a positive influence in maintaining the natural

93 habitats (Paiva, Brites, \& Machado, 2015), and on their ability to sustain higher levels of

94 biodiversity (Gray et al., 2016; Thomas \& Gillingham, 2015); with the differences mostly

95 attributable to differences in land use between protected and unprotected sites (Gray et al.,

96 2016).

Thus, to maximize conservation outcomes, it is crucial to identify areas with the greatest potential to expand protected areas. Nevertheless, this comes with the risk of ineffective outcomes due to land use change and uncoordinated actions between countries (Pouzols et al., 2014). Previous studies have shown that under different scenarios of land use change it might become infeasible to achieve the $17 \%$ of terrestrial land protected, which when combined with increasing land use change threatens a high number of species (Pouzols et al., 2014). Also, a continued decline of primary vegetation lands within the areas surrounding protected areas is expected thus leading to an increasingly heterogeneous matrix of primary and human-modified landscapes (Beaumont \& Duursma, 2012).

For the foreseeable future, the fate of terrestrial ecosystems and the species they support will continue to be intertwined with human systems, as most of the remaining natural areas are now embedded within anthropogenic mosaics of land use. However, the rate and location of land use change required to meet the demand for commodities are highly uncertain as it depends on the trajectories of development that might unfold in the future. In this regard, a set of Shared Socio-economic Pathways (SSPs), associated with the Representative Concentration Pathways (RCPs), have been developed by the climate science community (O’Neill et al., 2017, 2014; Van Vuuren et al., 2011). Working under the Intergovernmental Panel on Climate Change (IPCC) auspices, these SSPs and RCPs describe different scenarios of human development trajectories that would result in different climate futures based on land use change projections and greenhouse gas emissions over the $21^{\text {st }}$ century (Popp et al., 2017; Riahi et al., 2017). In particular, the SSPs explore a wide range of scenarios on climate change mitigation and adaptation, on technological improvements, on 


\section{\begin{tabular}{l} 
SSP Name \\
\hline SSP1: \\
sustainability - taking the green road
\end{tabular}}

SSP2:

middle of the road

SSP3:

regional rivalry - a rocky road

SSP4*:

inequality - a road divided

SSP5:

fossil-fueled development - taking the highway

\section{Short description}

The world transitions gradually to a more sustainable path, focusing more on environmental friendly practices, and healthier diets. Land use regulation is enforced, and crop yields increase rapidly, leading to lower rates of conversion.

The world does not shift significantly from historical patterns. Land use regulation is incomplete and crop yields slowly decline over time. Before 2030 there are no incentives towards avoided deforestation and afforestation.

The world evolves in an unsustainable manner, focusing on domestic production of food (with unhealthy diets) and energy. Land use regulation is practically non-existent and crop yields decline over time. Forest mitigation activities are limited. The world moves towards increasing inequalities, such as land use regulation and crop yields increase occur only in richer countries. Medium level of healthy diets and limited incentives for avoided deforestation and afforestation before 2030 .

The world focus on technological improvements as a path to sustainability. Land use regulation is incomplete, but crop yields increase rapidly leading to lower conversion rates. Unhealthy diets focused on animal products consumption lead to high waste.

* SSP4 has two land use projections based on two possible RCP combinations. impacts on climate and ultimately human well-being, is thus important to understand how current conservation areas might be impacted by these projections of future land use change. Therefore, the main objective of this study was to investigate how future land use trajectories, representing a wide range of plausible future scenarios (the five SSPs), would impact areas of 
135 primary vegetation under different protection, across the world's biomes from 2015 through

136 2090. With such analysis, we aimed to highlight areas under greater risk of conflict between

137 conservation (highly protected) and land use expansion (high projected change), and areas

138 where these two can better co-exist (lower protection with high projected change and/or high

139 protection with low projected change). Such results could help inform policy and decision-

140 makers to prevent such conflicts and support the development of management actions

141 targeting conservation in areas under expected great pressure of change and high ecological

142 value (e.g., composed mainly by primary vegetation), but still not protected (i.e., potential 143 areas to expand existing network of protected areas).

Methods

Input Data and Sources

We used the land use projections provided by the dataset of the Land Use Harmonized v2.0 project (http://luh.umd.edu/) (Hurtt et al., 2011; Hurtt et al., 2016). The dataset, which was produced within the context of the World Climate Research Program Coupled Model Intercomparison Project (CMIP6), contains a harmonized set of land use scenarios that are consistent between historical reconstructions and future projections. In detail, it contains annual land use maps, produced by different integrated assessment models (IAMs) for each SSP, from 2015 through 2100 at $0.25^{\circ}$ resolution, with the proportion of each pixel covered by each one of 12 land use classes (Table S1). In this study, we focused specifically on the loss of primary vegetation land (both forested and non-forested) given that protected areas are mainly implemented to protect pristine environments and not human-modified lands (Baldi et al., 2017; Paiva et al., 2015). The resolution of the land use time series dataset determined the spatial unit of analysis, and for each SSP we obtained a different time series of projected land use change according to the assumptions of each pathway (Table 1, see details in Riahi et al., 2017), and the model used to spatialize these assumptions (Popp et al., 2017). As we intended to focus our analysis only on the loss of primary vegetation, we aggregated the original land use classes into two: primary and modified as detailed in Table S1. LUH2 project are spatially and descriptively coarse. Although these categories have greatly improved since LUH1 (Beaumont \& Duursma, 2012), these still do not allow us to 
our analysis is blind to the detailed spatial configuration of loss in primary vegetation, i.e., whether a projected $10 \%$ loss in primary vegetation is adjacent to existing loss, or spread homogeneously across the grid cell.

Furthermore, we used the entire geodatabase of the World Database of Protected Areas (Brooks et al., 2004; Dubois et al., 2016), as of October 2018, to obtain the geographic location of all current protected areas in the world. From this dataset we produced a raster with the same extent and cell size as the land use dataset, containing the proportion of each grid cell that is covered by protected areas (regardless of its category of protection and not double-counting overlapping conservation status). We then classified each grid cell as belonging to one of the following five classes: 0 (no protection), 0-25\%, 25-50\%, 50-75\%, $>75 \%$ protected.

Finally, we used the biomes of the world (Figure S1) as made available by (Eric Dinerstein et al., 2017). From these data, we classified each of our $0.25 \times 0.25^{\circ}$ grid cell as belonging to only one biome, according to the majority class that covered that grid cell. This step allowed us to segment our global analysis and further understand the distribution and trends associated with each biome. All subsequent analyses were performed using the three datasets described above: land use change, protected areas and biomes.

\section{Land use change analyses}

We started our analyses by investigating the coverage of primary and modified areas in the present day (i.e., 2015) at the global scale, per biome and per class of protection. Next, we determined the proportion of primary and modified land that is under protection, as well as the average protection level of the grid cells within each biome. A correlation between the proportion of primary vegetation and proportion of protection was then tested for the hypothesis that higher protection classes would contain higher levels of primary vegetation. Such a hypothesis was assessed both globally and across biomes.

For each one of the SSPs investigated in this study, we assessed how much loss of primary vegetation is projected to occur, globally, per biome and per grid cell from 2015 through 2090, using a decadal interval. Such analysis was performed considering the whole dataset (i.e., regardless of the level of protection), as well as stratified by the five protection classes described before, i.e., to assess whether the loss in primary vegetation across SSPs 
198

199

200

201

202

203

204

205

206

207

208

209

210

211

212

213

214

215

216

217

218

219

220

was significantly different across classes of protection. The significance across biomes and protection classes was assessed using a non-parametric Kruskal-Wallis test and subsequent pairwise comparison Mann-Whitney U-tests, using the Bonferroni correction, where relevant, using the statistical programme $\mathrm{R}$ (R Core Team, 2018).

To assess trends over time (from 2015 through 2090 on decadal intervals), we then computed a temporal vector for each grid cell depicting the loss of primary land over time, and implemented a linear regression, accounting for temporal autocorrelation, i.e., using a GLS algorithm, to identify the speed of change associated to each grid cell. Finally, the median slope values of the regressions across SSPs were computed and compared with the values of protection by overlaying the two datasets. A similar procedure was followed to compare the speed of change with original primary vegetation extent at the grid cell level. Moreover, we accumulated the values of change (2015-2090) at the biome, scenario and global scales, to make the same assessment considering the accumulated values, rather than the local (grid cell) values.

\section{Results}

Distribution of protected areas and primary vegetation areas globally and across biomes

We found that at the global scale by $2015,14 \%$ of the land surface (excluding water bodies) was under some level of protection (Figure 1b, Table 2). Considering cells under protection, on average each grid cell included $16 \%$ of protected land (standard error [s.e.] = $0.06 \%$; Figure S2), with a highly skewed distribution of $61 \%$ of cells unprotected, $19 \%$ with under $25 \%$ of the land protected, and only $11 \%$ of the grid cells were highly protected (>75\%). These proportions varied significantly across biomes (Kruskal-Wallis [KW] test; $\mathrm{H}$ $=13,345$, p-value $<0.001$ ), with the highest protection coverage in Montane Grasslands \& Shrublands (27\%), Flooded Grasslands \& Savannas (25\%), and Mangroves (24\%) (Table 2). Only six out of the fourteen biomes had a protection coverage above the 17\% Aichi Target, with Temperate Grasslands, Savannas \& Shrublands being the least protected with only $4 \%$ (Table 2). If we analyse the protection of primary vegetation at the grid cell level, we found that the distribution of cells under different levels of protection was highly skewed towards unprotected or low protection (0-25\%) globally, with again significant differences across biomes ( $\mathrm{KW}$ test; $\mathrm{H}=13,393$, p-value $<0.001$, Table 2). In this regard, the maximum proportion of unprotected cells occurred in Deserts \& Xeric Shrublands (78\%) and the 
230 minimum in the Mangroves biome (35\%). Contrarily, the highest proportion of highly 231 protected cells $(>75 \%)$ occurred in the biome Tundra $(25 \%)$, and the minimum in Temperate 232 Grasslands, Savannas \& Shrublands (1\%). On average, the highest protection coverage per 233 grid cell was found in the Montane Grasslands \& Shrublands $(28 \% \pm 0.32$, s.e.), and the 234 lowest values were found for Temperate Grasslands, Savannas \& Shrublands $(4 \% \pm 0.03$, 235 s.e.) (Figure S2).
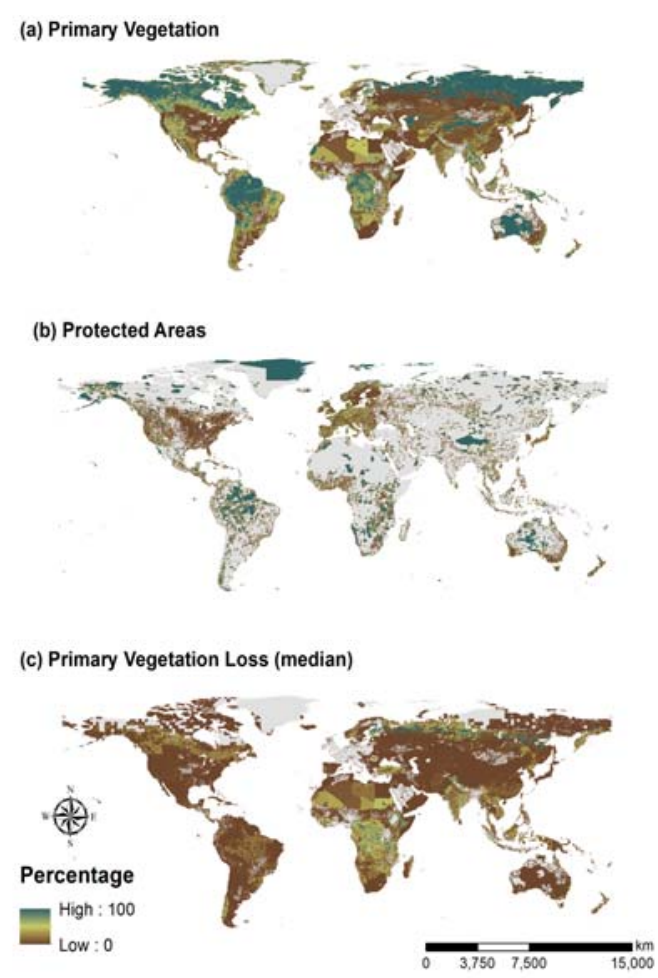

237 Figure 1 - Percentage of the grid cell covered in (a) primary vegetation in 2015, (b)

238 protected area and (c) median loss of primary lands across all SSPs by 2090, relative to 2015

239 (individual losses per SSP are shown in Figure S3).

240 Considering our 2015 baseline (Figure 1a), we found that, at the global scale, there 241 was a remaining $38 \%$ of areas considered as primary vegetation (forested or non-forested), 242 and $62 \%$ of the land had been modified from its natural state. Further, we found a weak 243 positive relationship $(\mathrm{t}$-value $=2.99, \mathrm{p}$-value $=0.06)$ between protection level and proportion 244 of natural areas (Table S2), i.e. more natural areas in higher protection cells. At the biome 245 level, there was once again sharp differences, where Temperate Grasslands, Savannas \& 246 Shrublands was the biome with the lowest percentage of primary vegetation areas (8\%), as 247 opposed to Tundra that was the highest (88\%) (Table 2). Within 57\% of the biomes, there 
248 was indeed a significant linear increase in the proportion of natural areas when considering

249 the protection level (Table S2). However, such coverage varied greatly when analyzed by

250 class of protection (Table 2), both globally and per biome. The average proportion of natural

251 areas per biome varied significantly both without considering the protection level (KW test;

$252 \mathrm{H}=35,245$, p-value $<0.001$ ), and when considering the cell protection (KW test; $\mathrm{H}=$

$25357,812, \mathrm{p}$-value $<0.001)$. In nine out the fourteen biomes, primary vegetation areas were

254 found in greater proportion than modified areas in the highly protected grid cells. On the

255 other hand, in two biomes (Tundra and Boreal Forests/Taiga) primary vegetation areas were

256 observed in higher proportion in unprotected cells.

257 Table 2 - Percentage (\%) of biome currently protected or considered primary vegetation, as a

258 whole, as well as considering only the area under different protection classes (from

259 unprotected [0] to more than $75 \%$ protected [>75]).

\begin{tabular}{|c|c|c|c|c|c|c|c|}
\hline Biome Name & Use & Whole & $\mathbf{0}$ & $0-25$ & $25-50$ & $50-75$ & $>75$ \\
\hline \multirow{2}{*}{$\begin{array}{l}\text { Tropical \& Subtropical Moist Broadleaf } \\
\text { Forests }\end{array}$} & Protected & 22.34 & 50.6 & 21.82 & 7.4 & 5.27 & 14.91 \\
\hline & Primary & 54.04 & 46.10 & 44.28 & 59.35 & 73.90 & 89.18 \\
\hline \multirow{2}{*}{$\begin{array}{l}\text { Tropical \& Subtropical Dry Broadleaf } \\
\text { Forests }\end{array}$} & Protected & 9.49 & 63.52 & 23.4 & 5.97 & 3.49 & 3.62 \\
\hline & Primary & 37.41 & 34.53 & 34.98 & 51.03 & 61.32 & 73.62 \\
\hline \multirow{2}{*}{$\begin{array}{l}\text { Tropical \& Subtropical Coniferous } \\
\text { Forests }\end{array}$} & Protected & 13.27 & 49.95 & 30.97 & 8.48 & 5.62 & 4.98 \\
\hline & Primary & 46.29 & 46.73 & 38.54 & 50.89 & 61.63 & 69.18 \\
\hline \multirow{2}{*}{ Temperate Broadleaf \& Mixed Forests } & Protected & 12.19 & 36.66 & 45.39 & 9.65 & 4.73 & 3.58 \\
\hline & Primary & 16.72 & 17.94 & 15.13 & 17.32 & 18.97 & 30.93 \\
\hline \multirow{2}{*}{ Temperate Conifer Forests } & Protected & 17.07 & 38.56 & 37.19 & 10.23 & 6.29 & 7.72 \\
\hline & Primary & 36.53 & 34.70 & 38.83 & 34.56 & 35.26 & 46.35 \\
\hline \multirow{2}{*}{ Boreal Forests/Taiga } & Protected & 10.7 & 70.44 & 15.82 & 3.91 & 2.87 & 6.96 \\
\hline & Primary & 64.6 & 68.43 & 51.38 & 62.58 & 71.32 & 83.37 \\
\hline \multirow{2}{*}{$\begin{array}{l}\text { Tropical \& Subtropical Grasslands, } \\
\text { Savannas \& Shrublands }\end{array}$} & Protected & 14.47 & 65.86 & 16.21 & 4.8 & 3.4 & 9.73 \\
\hline & Primary & 28.73 & 26.85 & 19.98 & 32.56 & 40.03 & 51.43 \\
\hline \multirow{2}{*}{$\begin{array}{l}\text { Temperate Grasslands, Savannas \& } \\
\text { Shrublands }\end{array}$} & Protected & 4.22 & 65.74 & 28.76 & 2.93 & 1.25 & 1.32 \\
\hline & Primary & 8.07 & 8.16 & 5.69 & 15.31 & 24.80 & 38.03 \\
\hline \multirow{2}{*}{ Flooded Grasslands \& Savannas } & Protected & 24.92 & 54.34 & 15.93 & 6.96 & 5.35 & 17.42 \\
\hline & Primary & 25.54 & 16.18 & 24.51 & 26.73 & 31.30 & 54.37 \\
\hline \multirow{2}{*}{ Montane Grasslands \& Shrublands } & Protected & 27.4 & 53.68 & 14.42 & 4.91 & 4.49 & 22.5 \\
\hline & Primary & 20.01 & 16.72 & 21.04 & 31.25 & 34.43 & 23.04 \\
\hline \multirow{2}{*}{ Tundra } & Protected & 10.35 & 66.26 & 4.57 & 2.33 & 2.11 & 24.72 \\
\hline & Primary & 88.47 & 96.26 & 82.15 & 86.72 & 87.72 & 95.51 \\
\hline \multirow{2}{*}{$\begin{array}{l}\text { Mediterranean Forests, Woodlands \& } \\
\text { Scrub }\end{array}$} & Protected & 17.53 & 35.56 & 39.03 & 12.5 & 6.59 & 6.32 \\
\hline & Primary & 17 & 19.36 & 11.15 & 22.05 & 26.44 & 26.41 \\
\hline \multirow{2}{*}{ Deserts \& Xeric Shrublands } & Protected & 10.95 & 77.94 & 9.11 & 2.88 & 2.26 & 7.81 \\
\hline & Primary & 31.29 & 28.53 & 28.43 & 37.38 & 44.69 & 57.46 \\
\hline
\end{tabular}




\begin{tabular}{llrrrrrr}
\hline \multirow{2}{*}{ Mangroves } & Protected & 24.16 & 35.25 & 30.38 & 12.64 & 8.87 & 12.86 \\
\cline { 2 - 7 } Globe & Primary & 29.99 & 29.00 & 31.14 & 48.93 & 54.31 & 61.35 \\
\hline \multirow{2}{*}{ Protected } & 14.20 & 61.30 & 19.23 & 5.07 & 3.40 & 11.00 \\
\hline
\end{tabular}

260

Projected changes in primary vegetation areas (2015-2090) globally and per biome

Each of the five scenarios of land use change (SSPs) led to an overall loss of primary vegetation areas from 2015 through 2090 (Figure 2, Table 3). At the global scale, this loss varied between $-17.4 \%$ in SSP1 to $-34.1 \%$ in SSP4 (RCP3.4), with an average of $-26.84 \%$ $(2.39 \%$ s.e.) across all scenarios (Figure 1c shows median value across all SSPs, whereas Figure S3 shows accumulated change in each individual SSP). Over time, when accumulated globally, the speed of primary vegetation loss (slope of regression, $\beta$ ) is sharper in SSP4 (RCP3.4) and slower in SSP1 $(\beta=-0.45$ and $\beta=-0.22$, respectively), and the same was observed when considered the local (grid cell average) values $(\beta=-0.50$ and $\beta=-0.32$, respectively, Figure S4). Further, this loss was higher in pixels with an initial higher proportion of primary vegetation in $2015(\mathrm{t}=180.03$, $\mathrm{df}=258,540$; $\mathrm{p}$-value $<0.001)$.

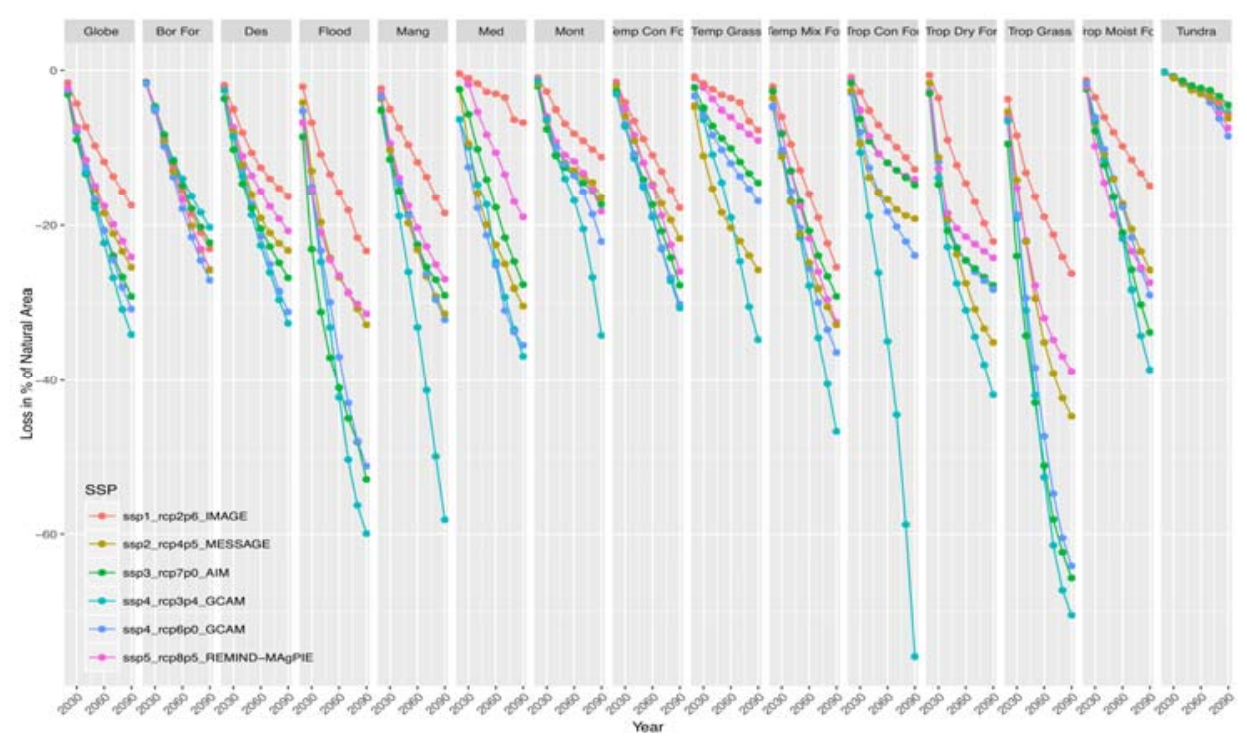

Figure 2 - Decadal loss in primary vegetation until 2090, relative to 2015 (in \%), globally and per biome, for each of the five land use scenarios (SSPs). Full biome names, Trop Moist For: Tropical \& Subtropical Moist Broadleaf Forests; Trop Dry For: Tropical \& Subtropical Dry Broadleaf Forests; Trop Con For: Tropical \& Subtropical Coniferous Forests; Temp Mix For: Temperate Broadleaf \& Mixed Forests; Temp Con For: Temperate Conifer Forests; Bor For: Boreal Forests/Taiga; Trop Grass: Tropical \& Subtropical Grasslands, Savannas \& 
279 Shrublands; Temp Grass: Temperate Grasslands, Savannas \& Shrublands; Flood: Flooded

280 Grasslands \& Savannas; Mont: Montane Grasslands \& Shrublands; Med: Mediterranean

281 Forests, Woodlands \& Scrub; Des: Deserts \& Xeric Shrublands; Mang: Mangroves.

We found strong variations across biomes within each scenario (KW test; average $\mathrm{H}=$ 54,510, 3596 s.e., p-value < 0.001) and across scenarios within each biome (KW test; average $\mathrm{H}=6,664,2805$ s.e., $\mathrm{p}$-value $<0.001)$. The projected change in primary vegetation across SSPs, varied from a minimum of $-76 \%$ in SSP4 (RCP3.4) in Tropical \& Subtropical

Coniferous Forests, Savannas \& Shrublands to a maximum of $-4.5 \%$ in SSP3 in Tundra

(Table 3). On average, Tundra is the least impacted biome (-6.25\%, 0.58 s.e.), whereas

Tropical \& Subtropical Grasslands, Savannas \& Shrublands is the highest impacted biome (scenario for the two most highly protected biomes (Tundra and Boreal Forests), where SSP4 (RCP3.4) led to fewer losses (Figure S3 and S4).

Table 3 - Loss in primary vegetation area in each of the land use scenarios, relative to 2015 295 (in \%), per biome and globally.

\begin{tabular}{lcccccc}
\hline \multicolumn{1}{c}{ Biomes } & SSP1 & SSP2 & SSP3 & SSP4a & SSP4b & SSP5 \\
\hline $\begin{array}{l}\text { Tropical \& Subtropical Moist } \\
\text { Broadleaf Forests }\end{array}$ & -14.89 & -25.82 & -33.82 & -38.72 & -28.98 & -27.45 \\
\hline $\begin{array}{l}\text { Tropical \& Subtropical Dry } \\
\text { Broadleaf Forests }\end{array}$ & -22.13 & -35.11 & -27.82 & -41.93 & -28.27 & -24.25 \\
\hline $\begin{array}{l}\text { Tropical \& Subtropical Coniferous } \\
\text { Forests }\end{array}$ & -12.74 & -19.16 & -14.77 & -75.74 & -23.94 & -14.03 \\
\hline $\begin{array}{l}\text { Temperate Broadleaf \& Mixed } \\
\text { Forests }\end{array}$ & -25.44 & -32.82 & -29.14 & -46.72 & -36.41 & -32.47 \\
\hline Temperate Conifer Forests & -17.72 & -21.74 & -27.79 & -30.64 & -30.16 & -26.01 \\
\hline Boreal Forests/Taiga & -23.07 & -25.83 & -22.29 & -20.28 & -27.15 & -25.76 \\
\hline $\begin{array}{l}\text { Tropical \& Subtropical Grasslands, } \\
\text { Savannas \& Shrublands }\end{array}$ & -26.27 & -44.74 & -65.61 & -70.40 & -64.07 & -38.89 \\
\hline $\begin{array}{l}\text { Temperate Grasslands, Savannas \& } \\
\text { Shrublands }\end{array}$ & -7.65 & -25.81 & -14.51 & -34.75 & -16.84 & -8.99 \\
\hline Flooded Grasslands \& Savannas & -23.36 & -32.82 & -52.88 & -59.93 & -51.24 & -31.41 \\
\hline Montane Grasslands \& Shrublands & -11.15 & -16.41 & -17.30 & -34.20 & -22.12 & -18.21 \\
\hline Tundra & -5.67 & -6.11 & -4.48 & -5.46 & -8.42 & -7.37 \\
\hline $\begin{array}{l}\text { Mediterranean Forests, Woodlands } \\
\text { \& Scrub }\end{array}$ & -6.66 & -30.40 & -27.71 & -36.92 & -35.47 & -18.92 \\
\hline Deserts \& Xeric Shrublands & -16.25 & -23.28 & -26.83 & -32.63 & -31.15 & -20.75 \\
\hline Mangroves & -18.41 & -31.39 & -29.01 & -58.14 & -32.16 & -27.00 \\
\hline Globe & -17.40 & -25.47 & -29.15 & -34.09 & -30.79 & -24.14 \\
\hline
\end{tabular}


Projected changes in natural areas (2015-2090) globally and per biome considering

protection

When considering the protection level of each grid cell we found that the areas under greatest threat of conversion are mostly located in the unprotected and 0-25\% categories

(Figure 3), although there was still a large proportion of change in the highly protected areas (varying from $-18 \%$ to $-30 \%$, in SSP1 and SSP4a, respectively). Further, there was no significant correlation found between protection coverage and average proportion of vegetation loss $(\mathrm{t}=1.83, \mathrm{df}=258,540 ; \mathrm{p}$-value $=0.07)$.
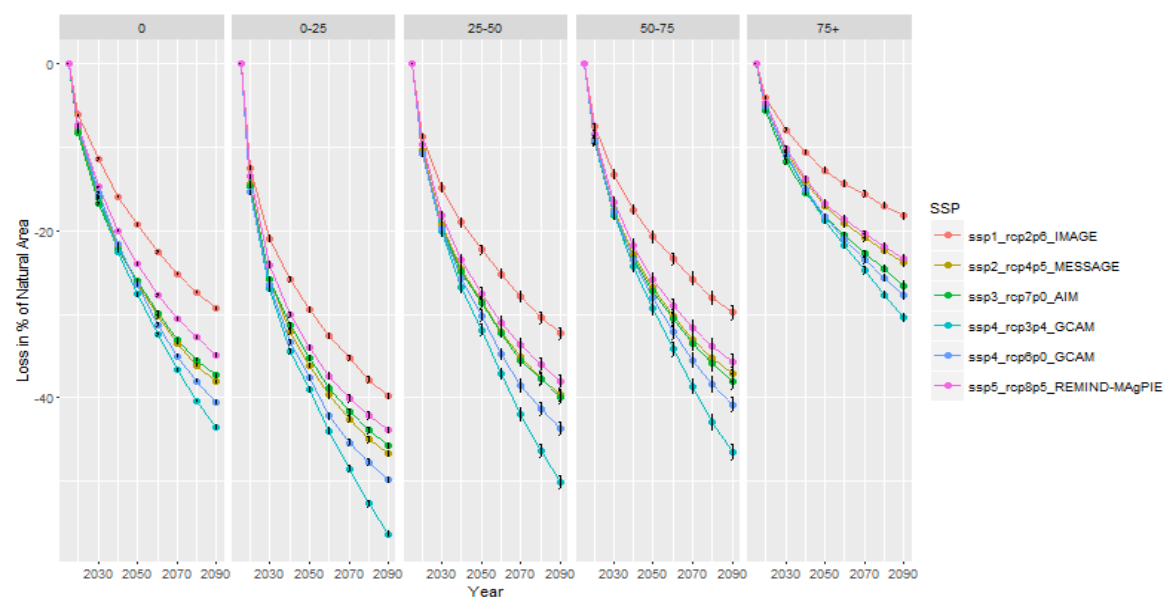

Figure 3 - Decadal average loss until 2090 (relative to 2015 in \%) within each scenario of

When averaging the overall change between 2015 and 2090 (across all scenarios), we found significant differences across biomes and protection level (Table S3). In detail, in the majority of the biomes the protection class with the highest projected loss in primary vegetation is either unprotected (in 7 out of 14 biomes) or low protection ( $0-25 \%$, in 5 out of 14 biomes). In the Mediterranean Forests, Woodlands \& Scrub the largest projected loss occurred in the highest protected grid cells, despite comprising the lowest proportion of cells in the Biome with only $6.32 \%$ of the grid cells falling in this protection category (Table 2). occurring, we overlapped the overall (and trend) in projected primary vegetation loss (20152090), with the protection class (Figure 4). We found that the Tropical Forests in Central 
319 Africa and the Boreal Forests of North Euro-Asia and Canada emerge as the areas where most projected change occurs in areas where existing protection coverage is still low.

321 Similarly, areas in India and Southeast Asia emerge as potential areas for intervention as they

322 have significant projected loss of primary vegetation, and considerably low (0-25\%) 323 protection.
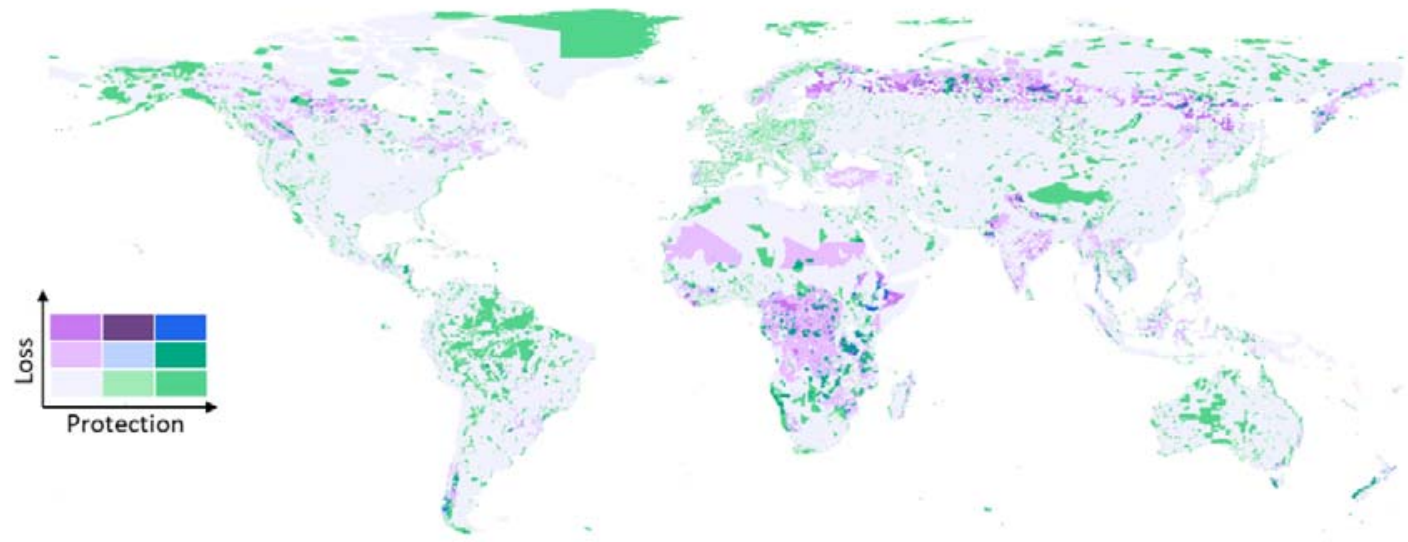

327 Figure 4 - Projected primary vegetation loss (median across SSPs, individual results for each 328 SSP in Figure S5) from 2015 through 2090, overlapped with proportion of protected (0-25\%, $25-75 \%,>75 \%)$.

\section{Discussion}

Despite international conservation efforts, particularly in relation to the expansion of protected areas worldwide (Thomas \& Gillingham, 2015), we have been unable to slow down the destruction of natural habitats, as recently highlighted by the IPBES Global Assessment (Díaz et al., 2019) and the near real time monitoring platform for forests, Global Forest Watch (Curtis, Slay, Harris, Tyukavina, \& Hansen, 2018). One of the key elements of biodiversity targets is the ability to preserve environmental representativeness, which has not

338 driven protected area expansion, with the focus placed on factors such as low productive value, population and tourism (Baldi et al., 2017). The presence of natural areas (primary vegetation) was highly skewed towards certain biomes (most under the desired 17\% protected coverage Aichi Target), and according to the modelled data used in our study, the weak 
relationship between the extent of the remaining natural areas and the extent of protection across biomes, suggests that we are endangering the representativeness of all biomes (as desired by the Aichi targets). These regions include some of the most biologically distinctive, species-rich ecosystems on Earth, such as tropical forests, thus compromising the preservation of genetic resources from a wide variety of life on Earth. Further, as highly protected cells tended to contain larger proportions of natural areas, the remaining natural areas of the world are becoming confined to current protected areas. This pattern highlights the need to ensure the efficacy of these areas in preventing further degradation, which has not always been the case (e.g., Rosa, Rentsch, \& Hopcraft, 2018; Soares-Filho et al., 2010). Further, there is a dichotomy between proportion of area covered and 'connectivity' of the protected areas network, for instance, biomes such as Temperate Grasslands, Savannas \& Shrublands emerged as having a high proportion of coverage (almost a quarter), but very fragmented, with a low proportion of full protected grid cells (1\%), suggesting low connectivity (Saura et al., 2017).

As we essentially failed to achieve the targets proposed by the CBD by 2020 (Amengual \& Alvarez-Berastegui, 2018), the new conservation agenda, at the global scale, is under discussion, with a great focus on restoring degraded ecosystems. For instance, the UN declared 2021-2030 as the Decade for Ecosystem Restoration, and recent studies (Bastin et al., 2019) state that planting forests (afforestation) would be the cheapest solution to address climate change. Nevertheless, it is critical to aid restoration with the preservation of the remains of natural vegetation as these contain the highest biodiversity levels (Newbold et al., 2015), genetic diversity, bank seeds, even in small patches (Wintle et al., 2019). Independently of the scenario followed, the current human development trajectories all lead to further primary vegetation loss. Despite numerous studies drawing attention to the disparities in habitat loss and protection (Hoekstra et al., 2005), and showing that halting agricultural expansion, increasing agriculture efficiency, shifting diets and reducing waste (Foley et al., 2011; Lambin \& Meyfroidt, 2011), would greatly help preserve existing habitats, the climate change community still largely ignores these aspects in their 'most positive' views of the world. Moreover, the recent IPBES call for transformative change in our society to preserve global biodiversity, make these novel visions (Rosa et al., 2017) influencing human development critically needed for our sustainability. In this context, our results show that even under the best possible scenario (SSP1) we will continue the 'anthropogenization' of our world (Ellis et al., 2010). This means that further biodiversity 
375 loss is unavoidable unless we act now to prevent further expansion of land use into natural 376 ecosystems (Pouzols et al., 2014).

377 Serious efforts to conserve the remaining $38 \%$ of natural areas need to target regions 378 of the world where land use change is expected to happen, thus avoiding or minimizes the 379 chances of that change to occur (pro-active rather than reactive conservation). On the one 380 hand, tropical forests in Central Africa and Southeast Asia, as well as natural vegetation in 381 India, emerge as highly likely to be destroyed (under all scenarios) and where protection 382 coverage is still low. As land use is a highly locked-in process (Guerra et al. under review), 383 i.e. once it changes it rarely reverses, this is the moment to rally internationally, support these 384 nations, and act before we lose these amazingly rich biodiversity hotspots. On the other hand, 385 Boreal forests, which still have low protected coverage (11\%), are likely to undergo extensive 386 land use change particularly under more 'aggressive' scenarios. Such areas may experience 387 even more important biological loss under the context of climate change, with impact on 388 species distribution (Tuanmu et al., 2013) and on carbon sequestration (Melillo et al., 2016).

389 Recent calls for more ambitious conservation targets (Mace et al. 2018), including to 390 protect half of the Earth's land area (Dinerstein et al., 2019; Dinerstein et al., 2017), seem 391 unlikely under the projected changes and given that we failed to achieve existing ones. This is 392 further highlighted by our inaction to address head-on the issue of feeding a growing 393 population with current dietary requirements (Mehrabi et al. 2018) or the teleconnections of 394 dispersed impacts between regions of the globe (Marques et al., 2019). More than defining 395 new area-based targets, a new paradigm that explicitly connects targets with indicators of 396 desired conservation outcomes (Barnes et al., 2018) needs to account for the expected 397 conflict between land use change (Wolff et al. 2018), protection of remaining native 398 vegetation, and restoration of degraded ecosystems under climate change. Apart from 399 improving the efficacy of existing protected areas, new conservation and restoration 400 mechanisms need to be developed to address this wicked challenge. Independently, proactive 401 conservation of the remaining natural vegetation is key to ensure the preservation of 402 biological diversity, aid the recovery of degraded habitats, and help to mitigate climate 403 change.

404

405 References 
406 Amengual, J., \& Alvarez-Berastegui, D. (2018). A critical evaluation of the Aichi

407 Biodiversity Target 11 and the Mediterranean MPA network, two years ahead of its 408 deadline. Biological Conservation, 225, 187-196.

409 Anthamatten, P., \& Hazen, H. (2015). Changes in the global distribution of protected areas, 410 2003-2012. The Professional Geographer, 67(2), 195-203.

411 Baldi, G., Texeira, M., Martin, O. A., Grau, H. R., \& Jobbágy, E. G. (2017). Opportunities $412 \quad$ drive the global distribution of protected areas. PeerJ, 5, e2989.

413 Bastin, J.-F., Finegold, Y., Garcia, C., Mollicone, D., Rezende, M., Routh, D., ... Crowther, 414 T. W. (2019). The global tree restoration potential. Science, 365(6448), 76-79.

415 Beaumont, L. J., \& Duursma, D. (2012). Global projections of 21st century land-use changes 416 in regions adjacent to protected areas. PloS One, 7(8), e43714.

417 Boserup, E. (2017). The conditions of agricultural growth: The economics of agrarian $418 \quad$ change under population pressure. Routledge.

419 Brooks, T. M., Da Fonseca, G. A., \& Rodrigues, A. S. (2004). Protected areas and species. $420 \quad$ Conservation Biology, 18(3), 616-618.

421 Curtis, P. G., Slay, C. M., Harris, N. L., Tyukavina, A., \& Hansen, M. C. (2018). Classifying 422 drivers of global forest loss. Science, 361(6407), 1108-1111.

423 Díaz, S., Pascual, U., Stenseke, M., Martín-López, B., Watson, R. T., Molnár, Z., ...

424 Brauman, K. A. (2018). Assessing nature's contributions to people. Science, $425 \quad 359(6373), 270-272$.

426 Díaz, S., Settele, J., Brondízio, E., Ngo, H., Guèze, M., Agard, J., ... Butchart, S. (2019).

$427 \quad$ Summary for policymakers of the global assessment report on biodiversity and 428 ecosystem services of the Intergovernmental Science-Policy Platform on Biodiversity $429 \quad$ and Ecosystem Services. 
430 Dinerstein, E., Vynne, C., Sala, E., Joshi, A. R., Fernando, S., Lovejoy, T. E., ... Baillie, J. E. Science Advances, 5(4), eaaw2869.

Dinerstein, Eric, Olson, D., Joshi, A., Vynne, C., Burgess, N. D., Wikramanayake, E., ... Noss, R. (2017). An ecoregion-based approach to protecting half the terrestrial realm. BioScience, 67(6), 534-545.

Dubois, G., Bastin, L., Bertzky, B., Mandrici, A., Conti, M., Saura, S., ... Boni, M. (2016). Integrating multiple spatial datasets to assess protected areas: lessons learnt from the Digital Observatory for Protected Areas (DOPA). ISPRS International Journal of Geo-Information, 5(12), 242.

Ellis, E. C., Klein Goldewijk, K., Siebert, S., Lightman, D., \& Ramankutty, N. (2010). Anthropogenic transformation of the biomes, 1700 to 2000. Global Ecology and Biogeography, 19(5), 589-606.

Ellis, E. C., \& Ramankutty, N. (2008). Putting people in the map: anthropogenic biomes of the world. Frontiers in Ecology and the Environment, 6(8), 439-447.

Foley, J. A., Ramankutty, N., Brauman, K. A., Cassidy, E. S., Gerber, J. S., Johnston, M., ... West, P. C. (2011). Solutions for a cultivated planet. Nature, 478(7369), 337.

Geldmann, J., Joppa, L. N., \& Burgess, N. D. (2014). Mapping change in human pressure globally on land and within protected areas. Conservation Biology, 28(6), 1604-1616.

Gibbs, H. K., Ruesch, A. S., Achard, F., Clayton, M. K., Holmgren, P., Ramankutty, N., \& Foley, J. A. (2010). Tropical forests were the primary sources of new agricultural land in the 1980s and 1990s. Proceedings of the National Academy of Sciences, 107(38), $16732-16737$. 
Gray, C. L., Hill, S. L., Newbold, T., Hudson, L. N., Börger, L., Contu, S., ... Scharlemann, worldwide. Nature Communications, 7, 12306.

Hoekstra, J. M., Boucher, T. M., Ricketts, T. H., \& Roberts, C. (2005). Confronting a biome crisis: global disparities of habitat loss and protection. Ecology Letters, 8(1), 23-29.

Hurtt, G. C., Chini, L. P., Frolking, S., Betts, R. A., Feddema, J., Fischer, G., ... Janetos, A. (2011). Harmonization of land-use scenarios for the period 1500-2100: 600 years of global gridded annual land-use transitions, wood harvest, and resulting secondary lands. Climatic Change, 109(1-2), 117.

Hurtt, G., Chini, L., Sahajpal, R., Frolking, S., Calvin, K., Fujimori, S., ... Heinemann, A. (2016). Harmonization of global land-use change and management for the period 850-2100. Geoscientific Model Development.

Jenkins, C. N., \& Joppa, L. (2009). Expansion of the global terrestrial protected area system. Biological Conservation, 142(10), 2166-2174.

Joppa, L. N., \& Pfaff, A. (2009). High and far: biases in the location of protected areas. PloS One, 4(12), e8273.

Lambin, E. F., \& Meyfroidt, P. (2011). Global land use change, economic globalization, and the looming land scarcity. Proceedings of the National Academy of Sciences, 108(9), $3465-3472$.

Marques, A., Martins, I. S., Kastner, T., Plutzar, C., Theurl, M. C., Eisenmenger, N., ... Bruckner, M. (2019). Increasing impacts of land use on biodiversity and carbon sequestration driven by population and economic growth. Nature Ecology \& Evolution, 1.

Melillo, J. M., Lu, X., Kicklighter, D. W., Reilly, J. M., Cai, Y., \& Sokolov, A. P. (2016). Protected areas' role in climate-change mitigation. Ambio, 45(2), 133-145. 
478 Newbold, T., Hudson, L. N., Hill, S. L., Contu, S., Lysenko, I., Senior, R. A., ... Collen, B.

479 (2015). Global effects of land use on local terrestrial biodiversity. Nature, 520(7545),

$480 \quad 45$.

481 O’Neill, B. C., Kriegler, E., Ebi, K. L., Kemp-Benedict, E., Riahi, K., Rothman, D. S., ...

482 Kok, K. (2017). The roads ahead: narratives for shared socioeconomic pathways

483 describing world futures in the 21st century. Global Environmental Change, 42, 169-

$484 \quad 180$.

485

O’Neill, B. C., Kriegler, E., Riahi, K., Ebi, K. L., Hallegatte, S., Carter, T. R., ... van Vuuren, D. P. (2014). A new scenario framework for climate change research: the concept of shared socioeconomic pathways. Climatic Change, 122(3), 387-400.

Paiva, R. J. O., Brites, R. S., \& Machado, R. B. (2015). The role of protected areas in the avoidance of anthropogenic conversion in a high pressure region: a matching method analysis in the core region of the Brazilian Cerrado. PloS One, 10(7), e0132582.

Popp, A., Calvin, K., Fujimori, S., Havlik, P., Humpenöder, F., Stehfest, E., ... Gusti, M. (2017). Land-use futures in the shared socio-economic pathways. Global Environmental Change, 42, 331-345.

Pouzols, F. M., Toivonen, T., Di Minin, E., Kukkala, A. S., Kullberg, P., Kuusterä, J., ... Moilanen, A. (2014). Global protected area expansion is compromised by projected land-use and parochialism. Nature, 516(7531), 383.

R Core Team. (2018). R: A language and environment for statistical computing. Retrieved from https://www.R-project.org/

Riahi, K., Van Vuuren, D. P., Kriegler, E., Edmonds, J., O’neill, B. C., Fujimori, S., ... Fricko, O. (2017). The shared socioeconomic pathways and their energy, land use, and greenhouse gas emissions implications: an overview. Global Environmental Change, 42, 153-168. 
503

504

505

Rosa, I. M., Pereira, H. M., Ferrier, S., Alkemade, R., Acosta, L. A., Akcakaya, H. R., ... Harfoot, M. (2017). Multiscale scenarios for nature futures. Nature Ecology \& Evolution, 1(10), 1416.

Rosa, I., Rentsch, D., \& Hopcraft, J. (2018). Evaluating Forest Protection Strategies: A Comparison of Land-Use Systems to Preventing Forest Loss in Tanzania. Sustainability, 10(12), 4476.

Saura, S., Bastin, L., Battistella, L., Mandrici, A., \& Dubois, G. (2017). Protected areas in the world's ecoregions: How well connected are they? Ecological Indicators, 76, 144158.

Schulze, K., Knights, K., Coad, L., Geldmann, J., Leverington, F., Eassom, A., ... Burgess, N. D. (2018). An assessment of threats to terrestrial protected areas. Conservation Letters, 11(3), e12435.

Soares-Filho, B., Moutinho, P., Nepstad, D., Anderson, A., Rodrigues, H., Garcia, R., ... Hissa, L. (2010). Role of Brazilian Amazon protected areas in climate change mitigation. Proceedings of the National Academy of Sciences, 107(24), 10821-10826.

Thomas, C. D., \& Gillingham, P. K. (2015). The performance of protected areas for biodiversity under climate change. Biological Journal of the Linnean Society, 115(3), 718-730.

Tuanmu, M.-N., Viña, A., Winkler, J. A., Li, Y., Xu, W., Ouyang, Z., \& Liu, J. (2013). Climate-change impacts on understorey bamboo species and giant pandas in China's Qinling Mountains. Nature Climate Change, 3(3), 249.

Van Vuuren, D. P., Edmonds, J., Kainuma, M., Riahi, K., Thomson, A., Hibbard, K., ... Lamarque, J.-F. (2011). The representative concentration pathways: an overview. Climatic Change, 109(1-2), 5. 
527 Watson, J. E., Dudley, N., Segan, D. B., \& Hockings, M. (2014). The performance and $528 \quad$ potential of protected areas. Nature, 515(7525), 67.

529 Wintle, B. A., Kujala, H., Whitehead, A., Cameron, A., Veloz, S., Kukkala, A., ...

530 Cadenhead, N. C. (2019). Global synthesis of conservation studies reveals the

531 importance of small habitat patches for biodiversity. Proceedings of the National Academy of Sciences, 116(3), 909-914.

533 